\title{
38. COMMENTS ON SOME COCCOLITHS AND SILICOFLAGELLATES FROM DEEP SEA DRILLING PROJECT LEG 35
}

\author{
David Bukry, United States Geological Survey, La Jolla, California
}

\section{INTRODUCTION}

Leg 35 of the Deep Sea Drilling Project, February to March 1974, which began at Callao, Peru, and ended at Ushuaia, Argentina, recovered 55 cores at four drilling sites, Sites 322-325 (Figure 1). Light-microscope techniques were used to examine the 13 samples available from the cores for study of coccoliths and silicoflagellates. Results of smear-slide examinations are summarized and some microfossils from the samples illustrated.

\section{SITE SUMMARIES}

Site 322

(lat $60^{\circ} 01.45^{\prime} \mathrm{S}$, long $79^{\circ} 25.49^{\prime} \mathrm{W}$, depth $5026 \mathrm{~m}$ )

Site 322 was drilled at the eastern end of the Bellingshausen Abyssal Plain to determine the age of basement of the Antarctic plate in the relatively unknown region of the southern Pacific north of Antarctica. Samples were available from 3 of the 14 cores attempted. The three diatomaceous silt samples lack coccoliths, but do contain a few silicoflagellates that indicate cool-water Neogene deposition. Although the specimen counts are low, Samples 322-1-1 and 322-1-2 appear to belong to the Pliocene portion of the Distephanus speculum speculum Zone (Bukry, 1974).

322-1-1, 123-124 cm (78 m):

Distephanus speculum speculum $82 \%$, Dictyocha $\mathrm{sp}$. cf. $D$. perlaevis delicatus $6 \%, D$ sp. cf. $D$. perlaevis perlaevis 6\%, and Mesocena sp. cf. M. diodon 6\%. Total count 17.

\section{2-1-2, 120-121 cm (80 m):}

Distephanus speculum speculum $87 \%, D$. sp. cf. $D$. speculum varians $4 \%$, Dictyocha aspera aspera $4 \%$, and Mesocena circulus 4\%. Total count 23.

322-4-2, 16-18 cm (354 m):

Distephanus sp. fragments and Mesocena sp. fragments.

\section{Site 323}

(lat $63^{\circ} 40.84^{\prime} \mathrm{S}$, long $97^{\circ} 59.69^{\prime} \mathrm{W}$, depth $4993 \mathrm{~m}$ )

Site 323 was drilled on the Bellingshausen Abyssal Plain to determine the nature of the regional sedimentation and the age of the basement rock. Nine samples were available from the 21 cores recovered below the sea floor to a depth of 731 meters. Of three samples from Core 1 ( 76 to $85 \mathrm{~m}$ ), only Sample $323-1-1,114-116 \mathrm{~cm}$ $(77 \mathrm{~m})$ contained any silicoflagellates or coccoliths. Though barren of coccoliths, the sample contains rare specimens of short-spined Distephanus speculum speculum and $D$. speculum binoculus.
Sample 323-3-2, 125-126 cm (258 m) lacks coccoliths, but contains a few silicoflagellates and common diatoms (including Raphidodiscus marylandicus), suggesting an early or middle Miocene age. The silicoflagellate assemblage contains 30\% Cannopilus ernestinae, $30 \%$ Distephanus speculum minuta, $20 \%$ D. crux s. ampl., and $20 \%$ Mesocena apiculata, based on a count of only 10 specimens. The stratigraphic restriction of Mesocena apiculata to middle Miocene or older assemblages at subantarctic Site 278 (Bukry, 1975) is the basis of correlation, because the species of Distephanus are long ranging, and the range of $C$. ernestinae is not yet established.

A low-diversity coccolith ooze of highly fragmented specimens occurs in three samples from Cores 15 and 16 (655 to $674 \mathrm{~m})$. All three samples are assigned to the early Paleocene Cruciplacolithus tenuis Zone, and the low diversity and lack of pentaliths and thoracospheres suggest an oceanic cool-water assemblage. The presence of Biscutum testudinarium (synonym: Conococcolithus? panis) and Hornibrookina teuriensis, recently described by Edwards (1973a, 1973b) from the early Paleocene of New Zealand and the Tasman Sea further supports the cool-water aspect of the assemblage.

Bramlette and Martini (1964) showed only four coccolith species-Markalius astroporus, Braarudosphaera bigelowii, Thoracosphaera sp. cf. T. imperforata, and $T$. operculata-common to the Maestrichtian and Danian, but admixture by reworking could not be totally dismissed. Perch-Nielsen $(1968,1969)$ demonstrated that species of Biscutum occurred in Late Cretaceous and Danian strata of Denmark, northern Europe, Africa, and North America. Reworking could not be completely dismissed, however, as other Cretaceous species, considered reworked, occurred with Biscutum in the Danian strata investigated. Edward's illustration of Biscutum-provisionally assigned to Conococcolithus?- shows the presence of the genus in the southwestern Pacific, again occurring in the Danian with other Late Cretaceous taxa such as Arkhangelskiella cymbiformis. At Site 323, Biscutum testudinarium is identified in Danian assemblages that lack any other Cretaceous species except Markalius astroporus and Zygodiscus sigmoides, both of which had previously been known to bridge the Cretaceous boundary, but to occur mainly in the Paleocene (Bramlette and Martini, 1964; Bukry, 1969). The assemblages at Site 323 help to establish that Biscutum can be considered indigenous in Danian assemblages around the world as indicated by Perch-Nielsen (1969). Species recorded from the samples are listed below:

\section{3-15-6, 121-123 cm (663 m):}

Biscutum testudinarium, Chiasmolithus sp. cf. C. danicus, Coccolithus pelagicus s. ampl., Fasciculithus? sp., Hornibrookina teuriensis, Markalius astroporus. 


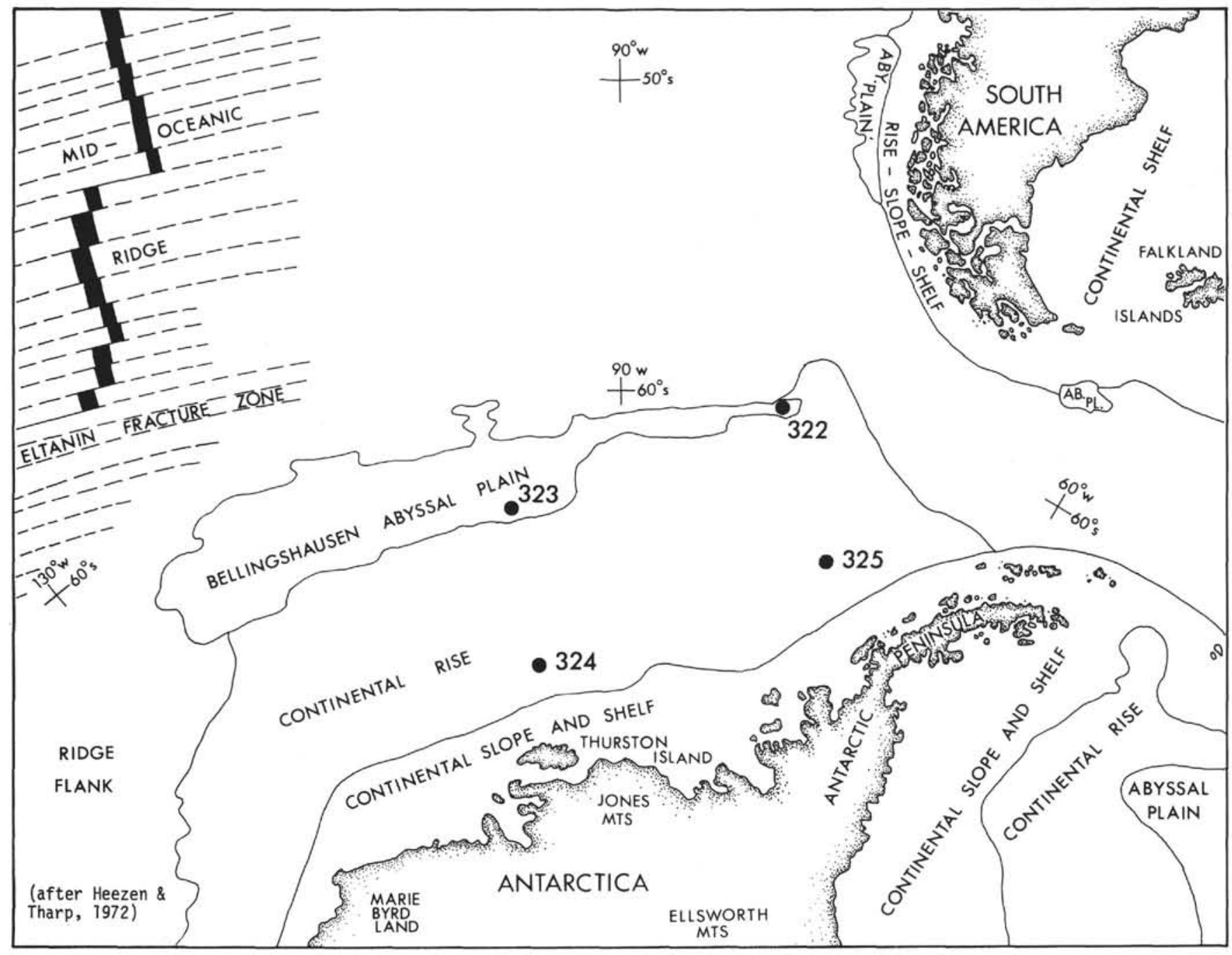

Figure 1. Deep Sea Drilling Project Leg 35 drilling sites.

\section{3-16-1, 126-128 cm (666 m):}

Biscutum testudinarium, Chiasmolithus sp. cf. C. danicus, Coccolithus pelagicus s. ampl., Cruciplacolithus tenuis, Hornibrookina teuriensis, Markalius sp. cf. M. astroporus, Zygodiscus sp. cf. Z. sigmoides.

\section{$323-16-2,96-98 \mathrm{~cm}(668 \mathrm{~m})$ :}

Biscutum testudinarium, Coccolithus pelagicus s. ampl., Cruciplacolithus sp. cf. C. tenuis, Markalius astroporus.

Samples 323-16-3, 120-121 cm (669 m) and 323-16-4, $125-126 \mathrm{~cm}(671 \mathrm{~m})$ are barren.

\section{Site 324}

(lat $69^{\circ} 03.21^{\prime} \mathrm{S}$, long $98^{\circ} 47.20^{\prime} \mathrm{W}$, depth $4449 \mathrm{~m}$ )

No samples available; see reports of shipboard scientists.

\section{Site 325}

(lat $65^{\circ} 02.79^{\prime} \mathrm{S}$, long $73^{\circ} 40.40^{\prime} \mathrm{W}$, depth $3745 \mathrm{~m}$ )

Site 325 was drilled on the continental rise northwest of the Antarctic Peninsula. Ten cores were taken below the sea floor to a depth of 718 meters. A sample from the only coccolith horizon encountered at this site, 325-8-2, $120-122 \mathrm{~cm}(615 \mathrm{~m})$, contains an abundance of small elongate specimens of Dictyococcites that are possibly related to Dictyococcites sp. cf. D. scrippsae, which is common; Coccolithus pelagicus s. ampl. is rare. The assemblage could range from Eocene to Pliocene in age on the basis of the Eocene to Oligocene range of Dictyococcites scrippsae and a propensity of Reticulofenestra pseudoumbilica s. ampl. (Miocene to Pliocene) to mimic $D$. scrippsae by heavy overgrowth of the central area (Bukry, 1972).

\section{REFERENCES}

Bramlette, M.N. and Martini, E., 1964. The great change in calcareous nannoplankton fossils between the Maestrichtian and Danian: Micropaleontology, v. 10, p. 291-322.

Bukry, D., 1969. Upper Cretaceous coccoliths from Texas and Europe: Kansas Univ. Paleont. Contrib., Protista, v. 2, p. 79.

, 1972. Coccolith stratigraphy Leg 9, Deep Sea Drilling Project. In Hays, J.E. et al., Initial Reports of the Deep 
Sea Drilling Project, Volume 9: Washington (U.S. Government Printing Office), p. 817-832.

1974. Stratigraphic value of silicoflagellates in nontropical regions: Geol. Soc. Am. Bull., v. 85, p. 1905-1906.

1975. Silicoflagellate and coccolith stratigraphy, Deep Sea Drilling Project Leg 29. In Kennett, J.P., Houtz, R.E., et al., Initial Reports of the Deep Sea Drilling Project, Volume 29: Washington (U.S. Government Printing Office), p. 845-872.

Edwards, A.R., 1973a. Calcareous nannofossils from the southwest Pacific, Deep Sea Drilling Project Leg 21. In
Burns, R.E., Andrews, J.E., et al., Initial Reports of the Deep Sea Drilling Project, Volume 21: Washington (U.S. Government Printing Office), p. 641-691.

, 1973b. Key species of New Zealand calcareous nannofossils: New Zealand J. Geol. Geophys., v. 16, p. 68-89. Perch-Nielsen, K., 1968. Der Feinbau und die Klassifikation der Coccolithen aus dem Maastrichtien von Dänemark: Biol. Skr. Danske Vidensk. Selsk., v. 16, p. 1-96.

1969. Die Coccolithen einiger Dänischer Maastrichtien- und Danienlokalitäten: Geol. Soc. Denmark Bull., v. 19, p. 51-69. 


\section{PLATE 1}

Silicoflagellates from Leg 35

Magnification $800 \times$; scale bar, $10 \mu \mathrm{m}$

Figures 1-6

Figure 7

Figure 8

Figure 9
Cannopilus ernestinae Bachmann.

Sample 323-3-2, 125-126 cm (258 m).

1-3. Side view; low, mid, and high focus.

4-5. Top view; high, mid, and low focus.

Dictyocha sp. cf. D. perlaevis delicata Bukry. Sample 322-1-1, 123-124 cm (78 m).

Distephanus crux (Ehrenberg) s. ampl. Sample 323-3-2, 125-126 cm (258 m).

Distephanus speculum speculum (Ehrenberg). Sample 322-1-1, 123-124 cm (78 m). 


\section{PLATE 1}
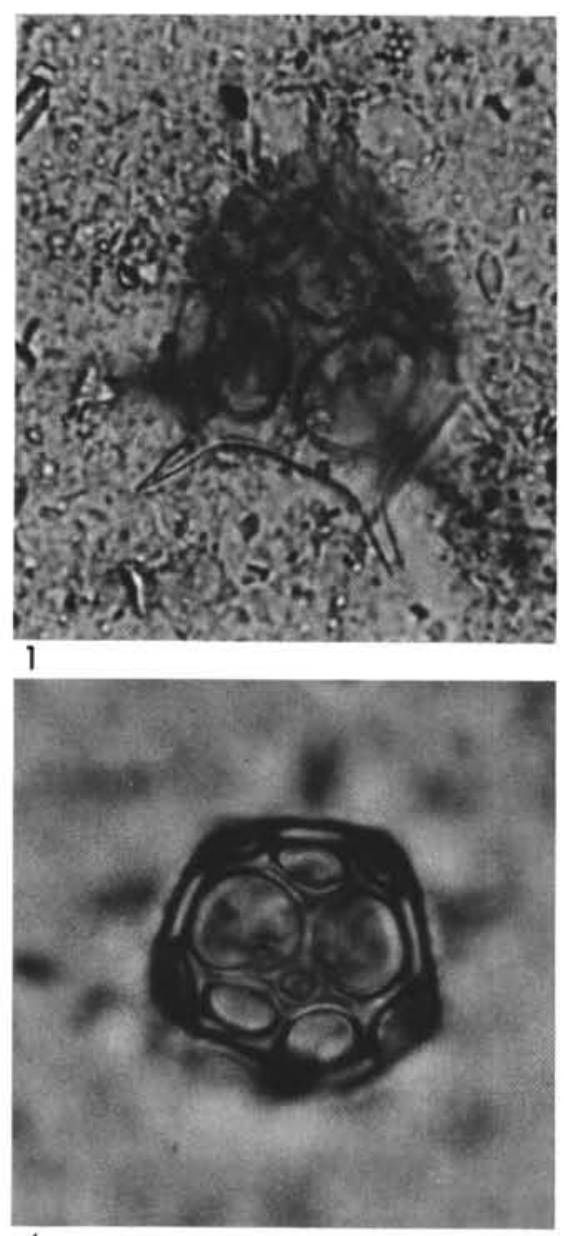

4

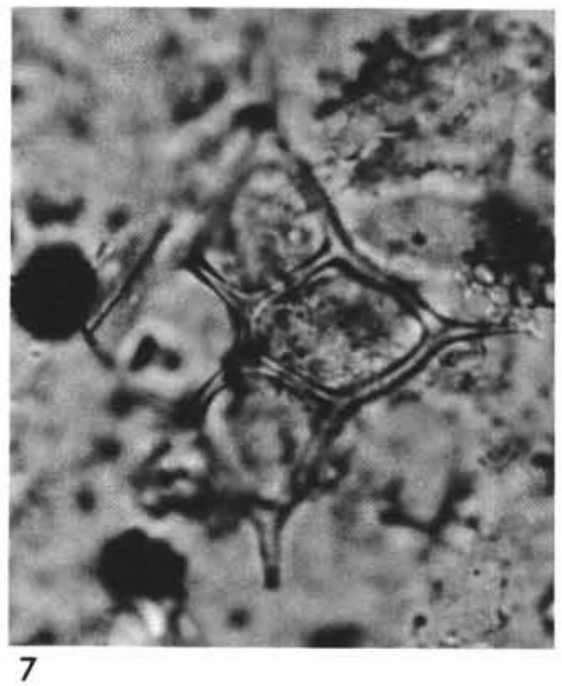

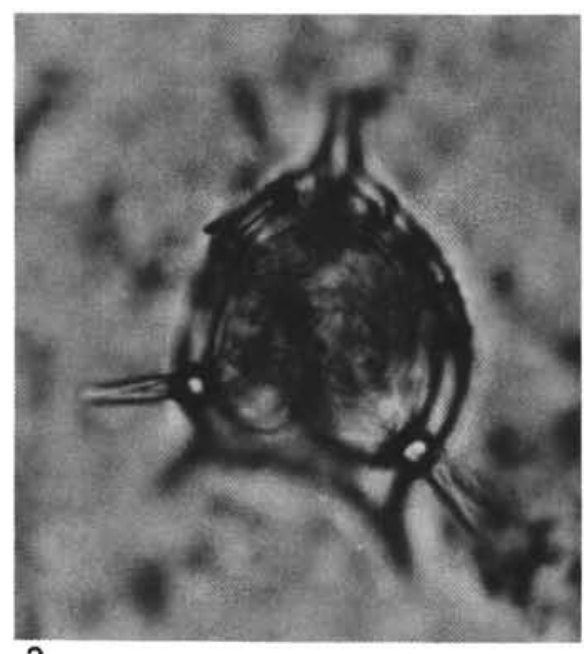

2

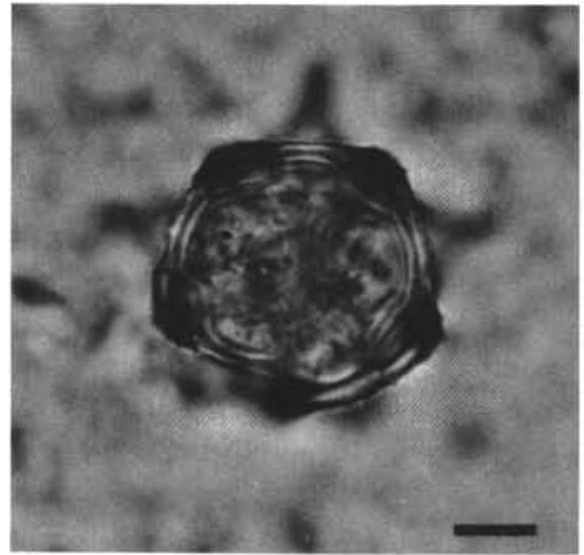

5

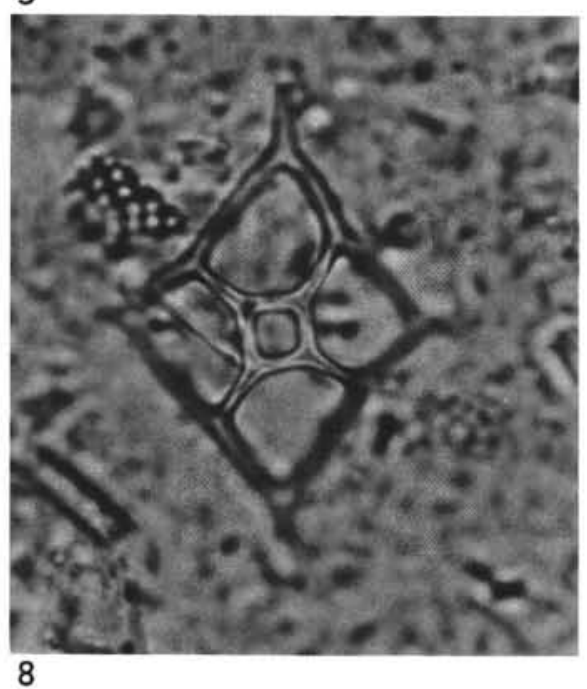

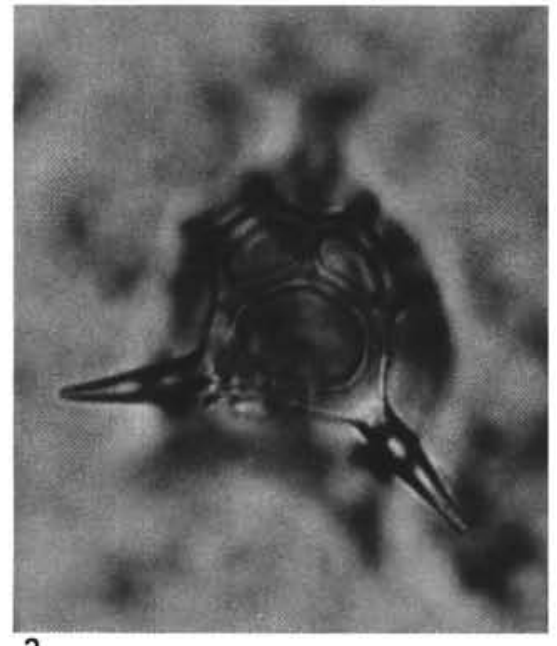

3

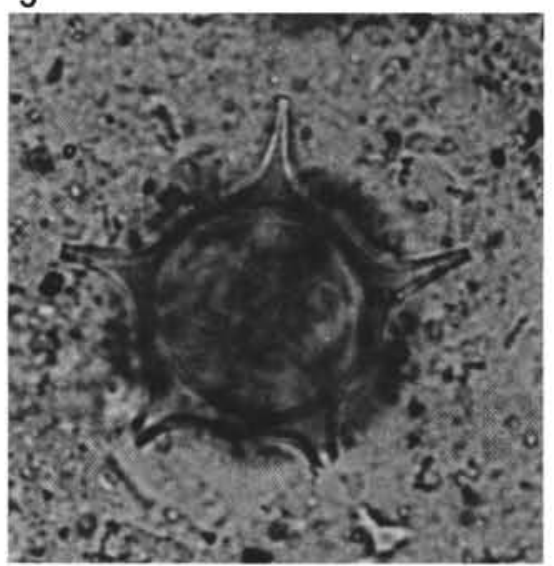

6

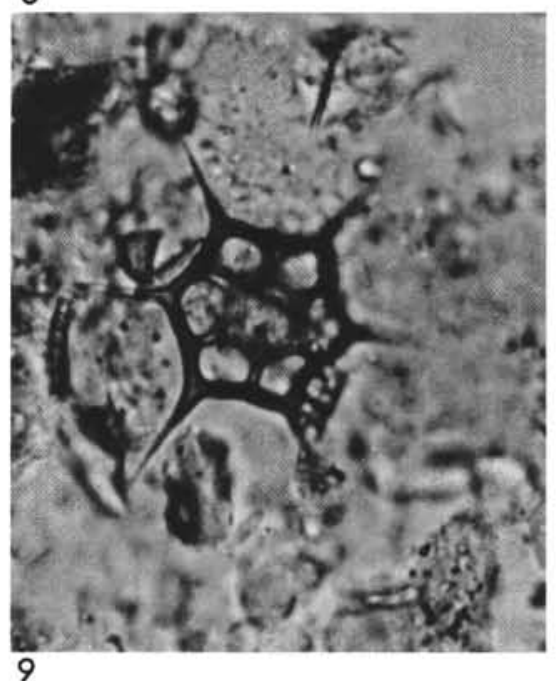




\section{PLATE 2}

Silicoflagellates (1-2), diatoms (3-5), and endoskeletal dinoflagellates (6-9) from Leg 35.

Magnification $800 \times$; scale bar, $10 \mu \mathrm{m}$.

Figure 1 Mesocena apiculata (Schulz).

Sample 323-3-2, 125-126 cm (258 m).

Figure 2 Mesocena sp. cf. M. diodon Ehrenberg. Sample 322-1-1, 123-124 cm (78 m).

Figures 3,4 Dicladia sp. cf. D. pylea Hanna and Grant.

3. Sample $322-1-2,120-121 \mathrm{~cm}(80 \mathrm{~m})$.

4. Sample $322-1-1,123-124 \mathrm{~cm}(78 \mathrm{~m})$.

Figure $5 \quad$ Thalassiosira $\mathrm{sp.}$

Sample 322-1-1, 123-124 cm (78 m).

Figures 6-9 Actiniscus pentasterias Ehrenberg. Sample 323-3-2, 125-126 cm (258 m).

8,9 . Low and high focus, same specimen. 
PLATE 2

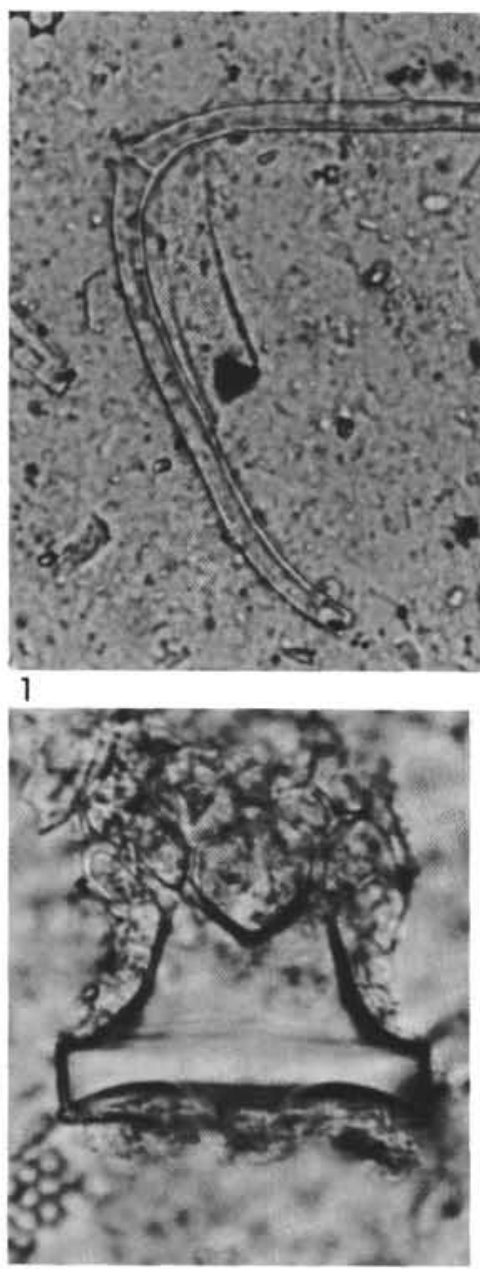

3

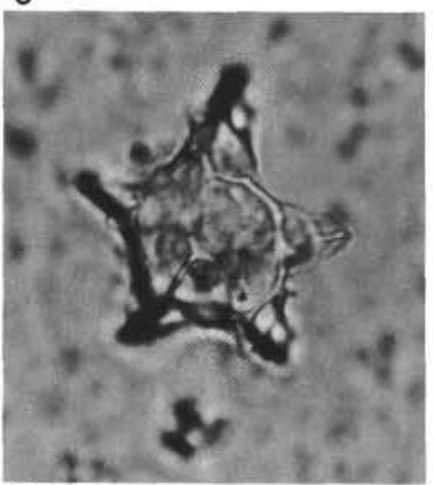

6
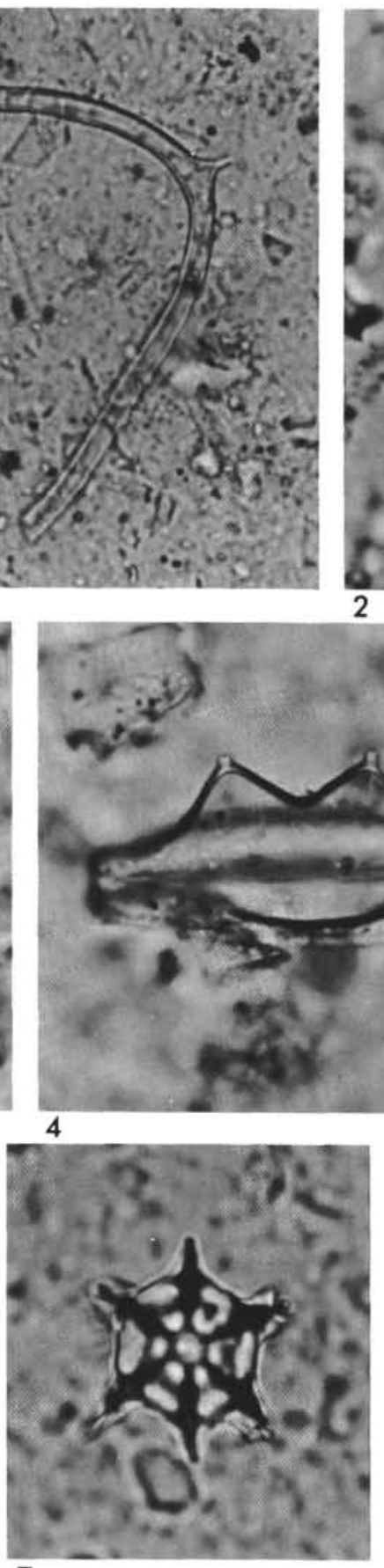

7

2
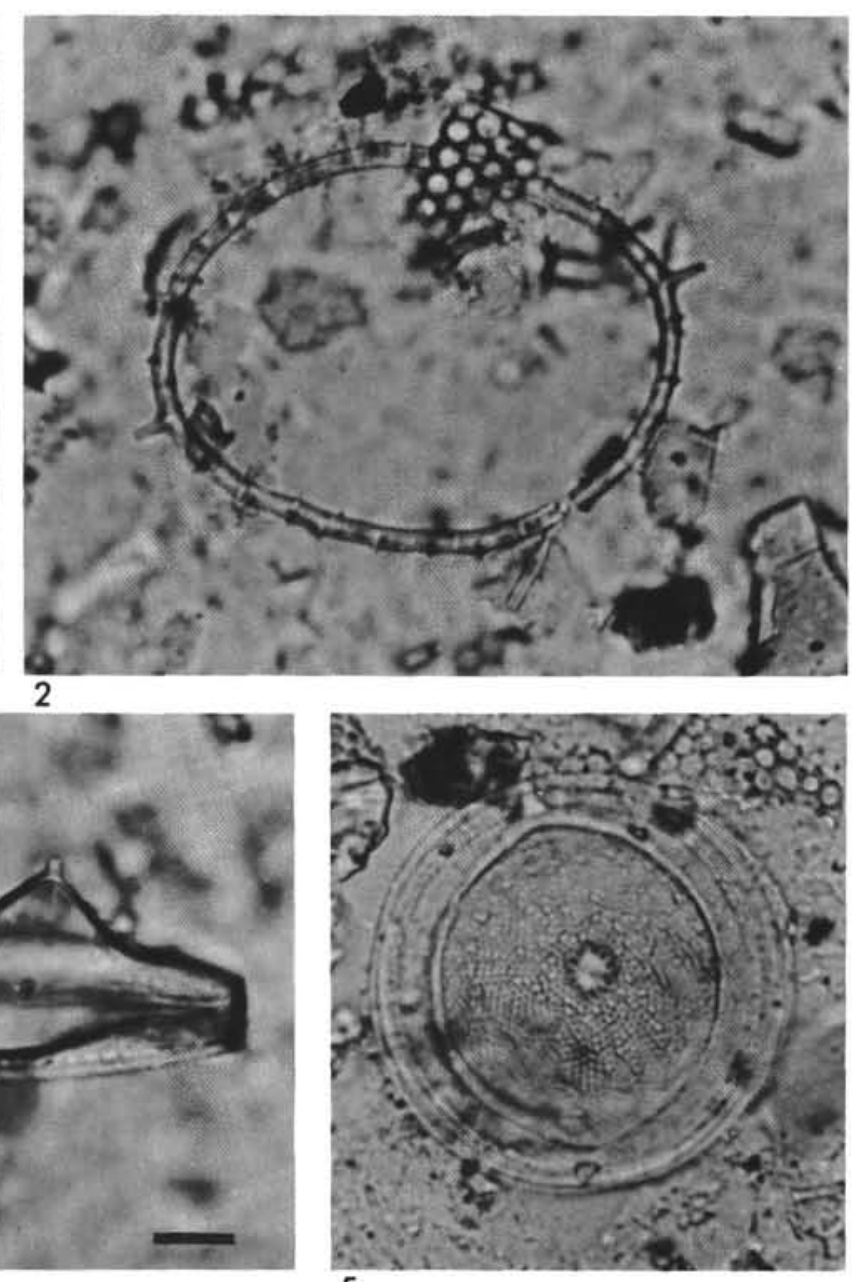

5

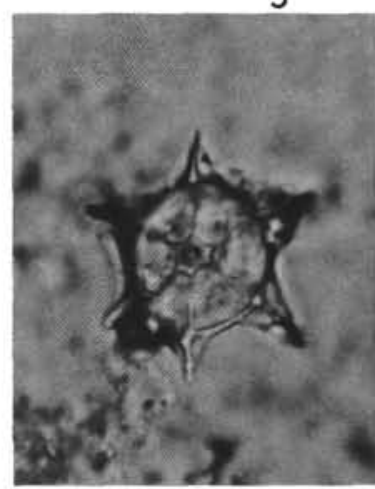

8

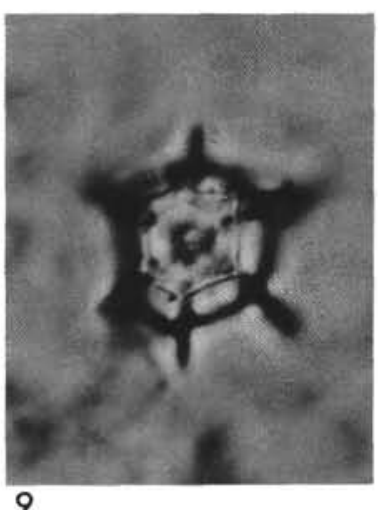

